\title{
ペリ環状反応を基盤とする新規複素環合成反応
}

\author{
早川 謙二*
}

\section{New Development in Heterocyclic Synthesis through Pericyclic Reactions.}

\author{
Kenji HAYAKAWA*
}

\begin{abstract}
New approaches to the heterocyclic syntheses through pericyclic reactions are presented in three sections.
(1) The utility of (phenylsulfonyl)propadiene (1) as an allenic dienophile and/or electrophile was revealed by its facile intermolecular cycloaddition reactions with electron-rich dienes, tropone, azaheptafulvenes, and thebaine derivatives, which afforded various heterocyclic compounds including some novel ring systems. (2) trans-4-(Phenylsulfinyl)-3-buten-2-one (29) underwent a new versatile addition-elimination (trans-vinylation) reaction with five-membered heterocycles such as furans, pyrroles, imidazole, pyrazole, and 6-(dimethylamino) fulvene to give excellent yields of the corresponding vinylated compounds. This method combined with the intramolecular Diels-Alder reaction was applied to the synthesis of linearly condensed tricyclic heterocycles like psoralen (31) and the novel aza-analogue of psoralen (38). (3) Intramolecular cycloaddition (ex.,Diels-Alder reaction) using allenic dienophiles proceeded with extraordinary ease due to their favorable geometry. These reactions were successfully utilized in the development of new polycyclic lactone synthesis, furan ring transfer (FRT) reactions, tandem intramolecular [2+2]-cycloaddition, [3,3]-sigmatropic rearrangement, and indole synthesis. Application of some of these new methods to the natural products synthesis is also described.
\end{abstract}

\section{1.はじめに}

近年量子化学の進歩は目ざましく, 有機化学の様々な 現象が分子軌道理論を駆使して説明され，化学反応の本 質的な問題を理解するのに大いに貢献してきた。特に有 機合成化学においては，フロンティア電子論を中心とす る福井理論1 ${ }^{1}$ や Woodward-Hoffmann 則 ${ }^{2)}$ が発表される に伴い,これらを理論的背景とした多くの “ペリ環状反 応” が次々と開発され, 複雑な構造を有する有機化合物 の合成を飛躍的に容易にしてきたのみならず，反応の許 容・禁制についてあるいは選択性についての理論的説明 や予測までもが可能になってきだ）。今日，ペリ環状反 応は炭素-炭素結合形成の有力な手段として高選択的分 子骨格構築や天然物合成などに広く活用されており，有

* 九州大学薬学部薬品製造化学講座

* Institute of Synthetic Organic Chemistry, Faculty of Pharmaceutical Sciences, Kyushu University 62
機合成化学の重要な一分野になっている4)。

ペリ環状反応 ${ }^{5)}$ は, 環状の遷移状態を経由して進行 する多点同時反応の総称であり, その最大の特徴は, 一 挙に複数個の炭素-炭素(へテロ原子) 結合を高選択的に 形成或は開裂することができる点にある。この際，フロ ンティア軌道論によれば, 反応を支配する重要な因子は 反応分子の最高被占軌道 (HOMO) と最低空軌道 (LUMO) の相互作用であり，両軌道間のエネルギー差が小さくな る程反応性は高くなる。また, 反応の選択性は軌道の係 数によって決まり，係数の大きい位置同志が相互作用す るような遷移状態がエネルギー的に有利となる。これら の電子的効果は, 反応に関与する分子 A,B が比較的自 由に接近できる分子間反応 (図 1a)の場合に特に有効に

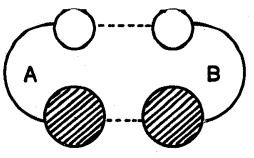

a) intermolecular

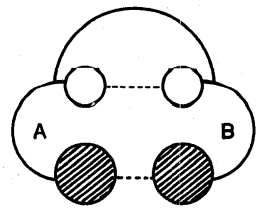

b) intromolecular

Fig. 1 
働くが6 10)，両者の接近方法に一定の制限がある分子 内反応 (b) の場合には, 上記の電子的効果に加えて, 立 体的要因や幾何学的要因の重要性が増してくる。即ち両 者が空間的に接近する際の立体障害の有無やその程度が 反応を支配する重要な要素になってくる。筆者らは，以 上の点を十分考虑にいれてペリ環状反応を基盤とした新 規複素環合成反応の開発や試薬設計を行ってきた。本稿 では，最近の研究成果を中心に，その考え方と有機合成 への応用について紹介する。

\section{2. フェニルスルホニルアレン}

2.1. アレン合成等価体 ${ }^{11}$ ) Diels-Alder 反応 (以 下 D.A.反応と略す)においてアレンを親ジエン物質と して用いれば，テルペン系天然物の部分構造として知ら れるメチレンシクロヘキセン骨格の簡易合成法となりう る。しかしながら，アレン自身の親ジエン性は低く， D.A.反応についても殆んど研究されていない12)。その 理由の一つに，ジエンージエノフィル間の有効な電子的 相互作用の欠如が考えられる。そこでスルホニルアレン (1) ${ }^{13)}$ をアレンの合成等価体として用いることを考え た。1のフェニルスルホニル基は強力な電子吸引基とし てアレンを電子的に活性化して環状付加を容易にするだ けでなく, 付加体の化学変換 (例えば，アルキル化)をも 容易にする。そしてスルホニル基は適当な段階で除去す る事が可能なため，1はアレンの合成等価体となり得る (図 2)。実際に $\mathrm{CNDO} / 2$ 法により分子軌道計算を行う

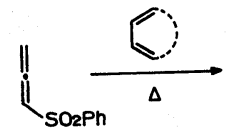

1

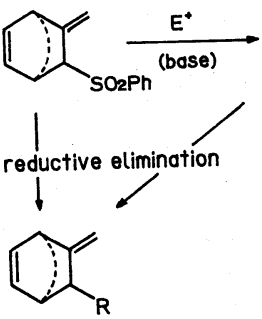

$(\mathbf{R}=H$ or $E)$

Fig. 2

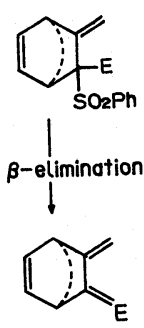
と, LUMO エネルギーレベルはアレンのそれに比べて 著しく低下しており $(\Delta \mathrm{E}=3.07 \mathrm{eV})$ ，また LUMO の係 数は 1,2-位に極在化しているごとが分かり，1は高い反 応性と共に高選択的(位置選択的，配向選択的)反応が期 待できる試薬である(図 3)。

2.2. 1,3-ジエン類との反応 スルホニルアレン 1 は表 1 に示す如く, 種々の電子豊富なジエン類と容 易に反応して高収率で対応する付加体を与えた。また反<smiles>C=C</smiles><smiles>[1H]C=C[18OH]</smiles>
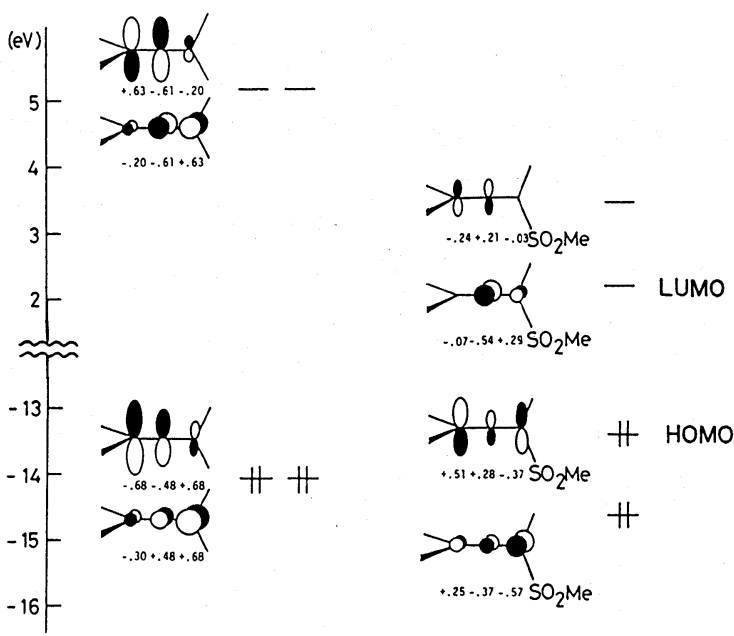

Fig. 3 Frontier molecular orbitals of allene and methylsulfonyl allene calculated by the $\mathrm{CNDO} / 2$ method.

応は予想通り位置選択的に進行し，アレンの 1,2-位で のみ付加体を形成する。更に, ジエン $5 \sim 8$ との反応 では高い配向選択性が見られ 0 -あるいは $p$-配向の生成 物のみが得られた。一方, 付加体の endo/exo 比 (立体選 択性)は電子的効果よりも立体的効果により強く支配さ れている。特に 7 との反応において exo-体 14 のみが生 成して扔り，スルホニル基はカルボニル基と異なり二次 軌道効果を示さないことが判かる。これらの付加体はい ずれもアリルスルホン構造を有しており， $\alpha$-アルキル 化 $\left(n-\mathrm{BuLi}, \mathrm{THF},-50^{\circ} \mathrm{C} ; \mathrm{RX}\right)$ が可能であるし，スルホニ ル基は還元的脱離 $(\mathrm{Na}-\mathrm{Hg} / \mathrm{MeOH})$ あるいは $\beta$-脱離 $(\mathrm{EtONa} / \mathrm{EtOH}) に よ り$ 容易に除去できることから，1は 有用なアレン合成等価体である ${ }^{11)}$ 。

\section{3. 中員環化合物との反応 ${ }^{11 ）} 1$ は中員環不飽} 和化合物とも興味ある反応性を示す。1とトロポン (16) を $100^{\circ} \mathrm{C}$ で反応させると exo-[8+2] 付加体 17 とフラン 誘導体 18 を与える (図 4)。後者は 17 の水素移動によ って生ずる熱力学的に安定な生成物である。一方，アザ ヘプタフルベン類 (19) とはアセトニトリル中室温でも 速やかに反応し, 最初にexo-[8+2]付加体 20 の生成が 見られ，引き続き $[1,3]$ および $[1,5]$ 水素移動が起こり 21 を経由して最終的に 22 を高収率で与える(図 4)。反 応の経過は ${ }^{1} \mathrm{H}-\mathrm{NMR}$ スペクトルにより容易に追跡する ことができる。上記の $[8+2]$ 反応において見られた高 い位置選択性, 配向選択性ならびにペリ選択性はフロン 
Table 1 Cycloaddition reactions of (phenylsulfonyl) propadiene (1) with 1,3-dienes (2-8).

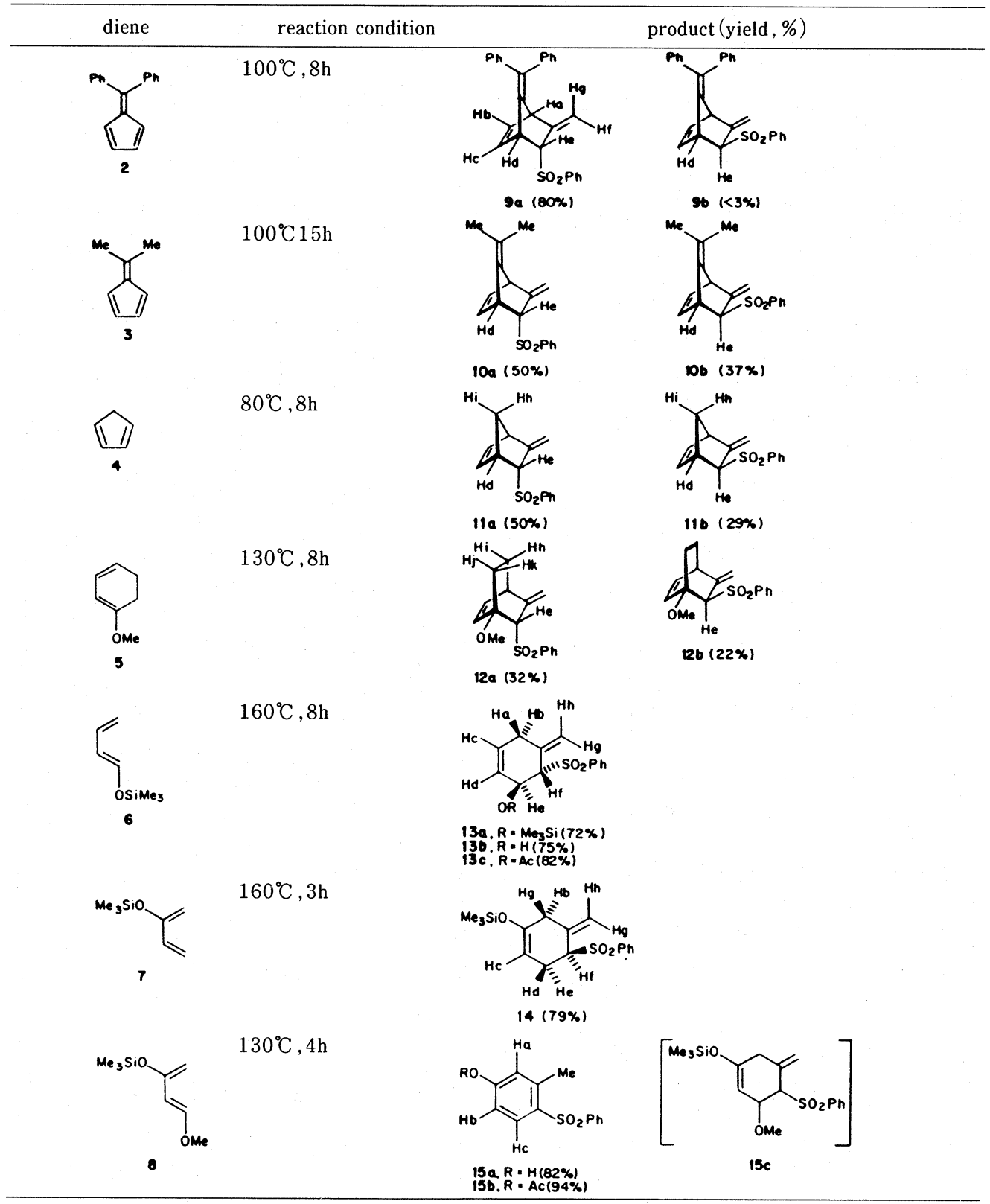

ティア軌道論から予測される結果と良い一致を示す。更 に, 各種溶媒中で反応速度を測定し溶媒極性との関係を 調べてみると, 図 5 に示す加くトロポンとの反応は殆 んど極性の影響を受けていないのに対し，アザヘプタフ ルベンの場合は著しい溶媒極性への依存性 (溶媒効果) が 見られ，前者が熱許容の協奏的反応であるのに対し後者 はイオン中間体 23 (図6)を経由する多段階反応である
可能性が高い。

2.4. テバイン類との反応 ${ }^{14 ）} 1$ が上記の如く LUMO 係数の最も大きい中央炭素上でへテロ原子の求 核攻撃を受け易いことに着目し15)，テバイン類の骨格 変換反応に応用した。テバイン類の窒素原子がアセチレ ン系親ジエン剂に対して高い求核性を示すことは既に当 研究室で明らかにされている ${ }^{16,17)}$ 。テバイン(24)およ 


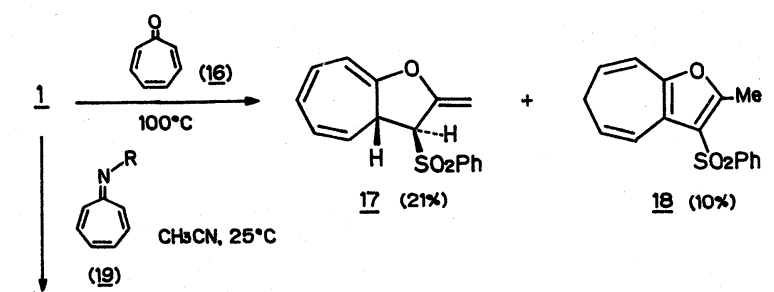

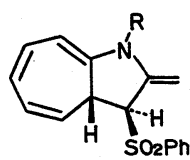

20

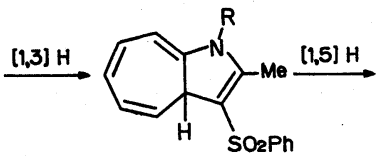

21

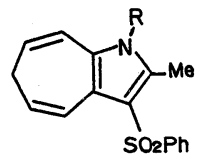

$22 \mathrm{~g}(80 \%)$ $\mathrm{b}(85 \%)$ a. 4-Cl- $\mathrm{C}_{6} \mathrm{H}_{4}-$ : $\quad$ b. 4- $\mathrm{CH}_{3}-\mathrm{C}_{6} \mathrm{H}_{4}-$;

Fig. 4

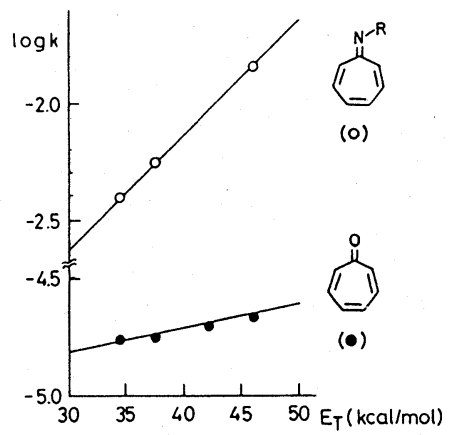

Fig. 5 Plots of $\log k$ vs. $E_{T}$ value for the reactions of 1 with $16(\bullet)$ and $19 \mathrm{~b}\left({ }^{\circ}\right)$

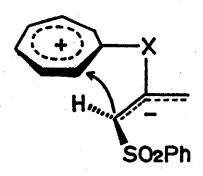

$\underline{23}$

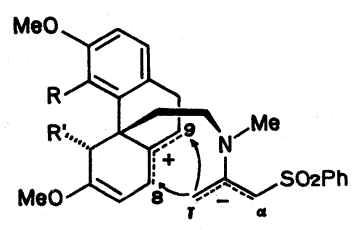

$\underline{28}$
Fig. 6

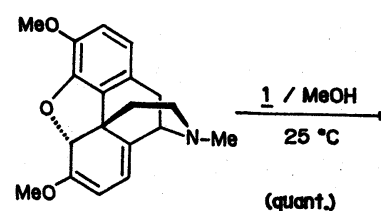

24

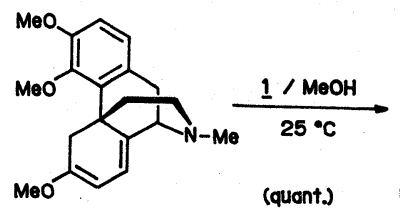

25

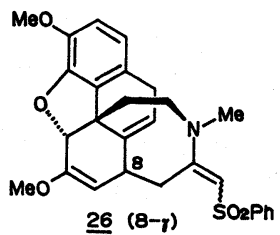

26 $(8-r)$

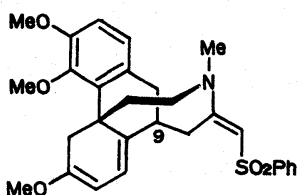

구 $(9-p)$
Fig. 7
び $\beta$-ジヒドロテバイン (25) は 1 とメタノール中室温で 速やかに反応して付加体 26 および 27 を定量的に与え る (図 7)。本反応はアセトニトリル中でも起こるが, ベ ンゼンのような非極性溶媒中では全く起こらないことか ら，窒素原子の求核攻撃に始まり，中間体 28 (図 6) を

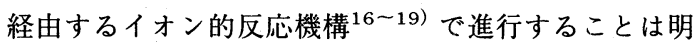
らかである。両性イオン中間体 28 のどの位置で再結合 が起こるか $(8-\gamma: 26 ， 9-\gamma: 27)$ は基質の立体的要因に より決まるものと思われる。1 は更にエナミン類とも 速やかに反応し, 中央炭素でのアルキル化が容易に起こ ることも明らかになった

以上の如くスルホニルアレン 1 は, LUMO レベルの 著しい低下からも予想される様に, 親ジエン試薬として も親電子試薬としても高い反応性を有していることが判

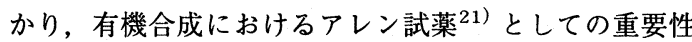
が今後一層増すであろう。

\section{3. $\beta$-スルフィニル- $\alpha, \beta$-不飽和カルボニル化 合物}

有用な合成試薬である $\alpha, \beta$-不飽和カルボニル化合物 の $\beta$ 位に電子吸引基であり，且つ脱離基でもあるスルフ イニル基を導入すると (ex.,29), LUMO レベルの低下 により親ジエン剤あるいは Michael 受容体としての反応 性の向上が期待できると共に，付加体からスルフェン酸 が脱離してエノン構造を再生することができ，その合成 的有用性を一層増大することになる(図 8)。事実,

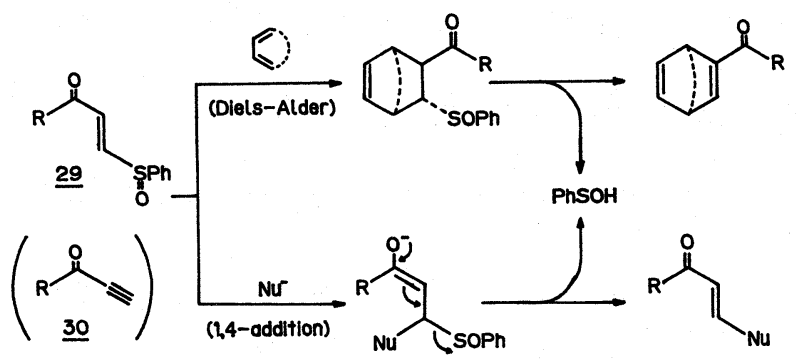

Fig. 8

$\mathrm{CNDO} / 2$ 法により分子軌道計算を行うと LUMO レベル は，メチルビニルケトン $(2.86 \mathrm{eV}), 3$-ブテン-2-オン $(3.24 \mathrm{eV})$ ，および 4 - (メチルスルフィニル) -3-ブテン -2-オン $(0.96 \mathrm{eV})$ となり, 予想通り 29 型化合物の LUMO レベルが著しく低下していることが判かり，30 型化合物よりも高い反応性を有することが期待される。

3.1. ビニル化反応 ${ }^{22}$ ４-(フェニルスルフィニ ル) - 3-ブテン-2-オン $(t-\mathrm{SBO})$ と各種ジエン類との反応 を検討したところ， 5 員環複素環化合物とは極めて容易 
に反応して，エノン残基がトランス型に導入されること を見いだした(表 2)。反応は無溶媒でも進行するが少量

Table 2 Addition-elimination reactions of $t$ SBO (1) with five-membered aromatic compounds.
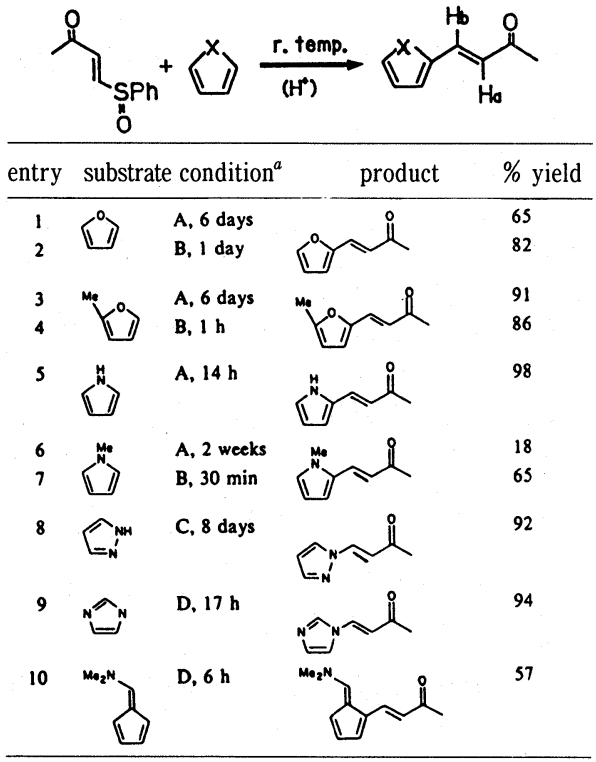

${ }^{\text {a }}$ All reactions were carried out at $25^{\circ} \mathrm{C}$ under the following conditions (for 1 equiv of 1 ): (A) excess of substrate ( $\sim 10$ equiv), neat; (B) excess of substrate ( $\sim 10$ equiv), $p$ - TsOH (catalyst), neat; (C) 1.2 equiv of substrate, $\mathrm{CH}_{3} \mathrm{CN}$; (D) 1.2 equiv of substrate, $p$ - $\mathrm{TsOH}$ (catalyst), $\mathrm{CH}_{3} \mathrm{CN}$.

の酸により加速される。 $t-\mathrm{SBO}$ の代わりに 4-(フェニル スルホニル)-誘導体を用いると, Michael 型-付加体が 単離されることから, 本反応は Michael 付加-スルフェ ン酸脱離の機構で進行しているものと思われる。

3.2. ソラレンの合成 ${ }^{22)}$ 上記の反応により五員 環複素環化合物の $\alpha$ 位にビニル基を選択的に導入するこ とが容易になった。そこでこれに分子内 D.A.反応を組 み合わせることにより一挙に直線型に縮環した三環式複 素環化合物の合成が可能になると考え (双環形成反応) (式 1), ソラレン (31) の合成に応用した。ソラレンはフ

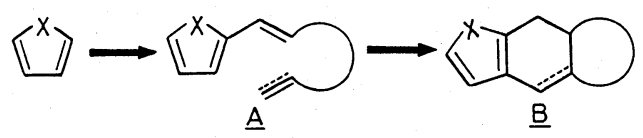

ロクマリン骨格を有する天然物で, DNA と高い親和性 を示し，紫外線照射によりチミン塩基部分と選択的に共 有結合を形成するなど発ガン機構解明の点からも注目さ れている物質であるが23)，従来の合成法はベンゼン誘 導体から出発するものに限られていた ${ }^{24)} 。$
まず必要となる分子内に親ジエン部分(三重結合)を有 するスルホキシド (32) は図 9 に示す方法でアセト酢酸

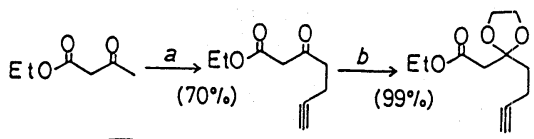

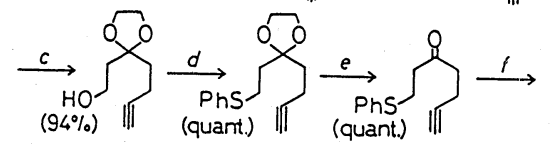

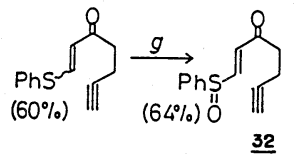

a (a) $\mathrm{LDA}$ (2 equiv), THF, then $\mathrm{CH} \equiv \mathrm{CCH}_{2} \mathrm{Br}$. (b) $\left(\mathrm{CH}_{2} \mathrm{OH}\right)_{2}$, $\mathrm{C}_{6} \mathrm{H}_{0 .}$ (c) concentrated $\mathrm{HCl}$, THF. (i) NCS, $\mathrm{C}_{6} \mathrm{H}_{0}$, then Et, $\mathrm{N}$. (B) $m$ - $\mathrm{CPBA}, \mathrm{CH}_{2} \mathrm{Cl}_{2}$, then $\mathrm{SiO}_{1}$ cliromatography.

Fig. 9

エステルから容易に合成できる。この際, $32(E / Z$ 混合 物) は $\mathrm{SiO}_{2}$-カラムクロマトグラフにより全て $E$-体へと 変化する。次に, 32 とフランを $p-\mathrm{TsOH}$ 存在下室温で 反応させると高収率 $(78 \%$ ) で 33 が得られた(図 10)。

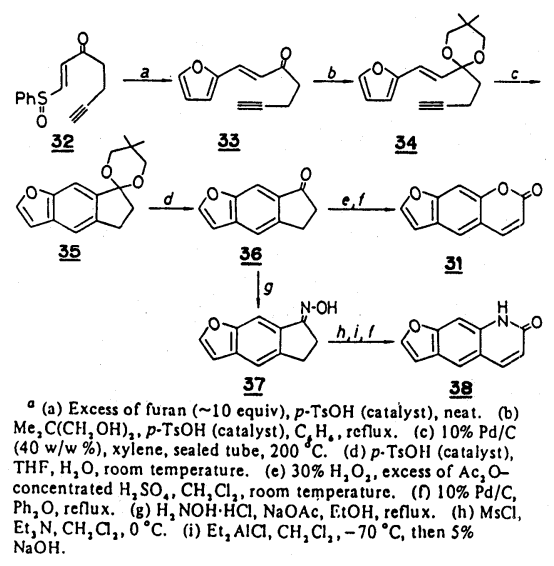

Fig. 10

33 の直接環化には成功しなかったが，ケトンをケター ル化 $(34,74 \%)$ した後, Pd-C 存在下 $200{ }^{\circ} \mathrm{C} に$ 加熱する と分子内 D.A. 反応と脱水素芳香族化が同時に起こり 35 を得た $(38 \%)$ 。この場合, 脱水素触媒 $(\mathrm{Pd})$ が存在し ないと五員環部分の開裂が起こりベンゾフラン誘導体を 主生成物として与える。35を脱ケタール化することに より重要中間体である三環式ケトン 36 を得た。36は Baeyer-Villiger 酸化した後に脱水素芳香族化を行うと ソラレン $31(28 \%)$ をちえるし，オキシム化(37)して

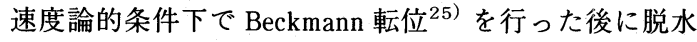
素芳香族化することによりソラレンの窒素類縁体 38 人 と変換することもできる。これらは複素環合成における 
双環形成反応の有用性を示すものである。

\section{4. アレン類の分子内環状付加反応}

4.1. アレニルエーテルの分子内 D. A. 反応 ${ }^{22)}$ ソラレン合成研究中, 分子内 D. A. 反応において親ジエ ン部分にアレニルエーテルを用いると，アリールエーテ ルやプロパルギルエーテルの場合に比べて, 著しく反応 が加速されることを見いだした（図 11）。分子軌道計算

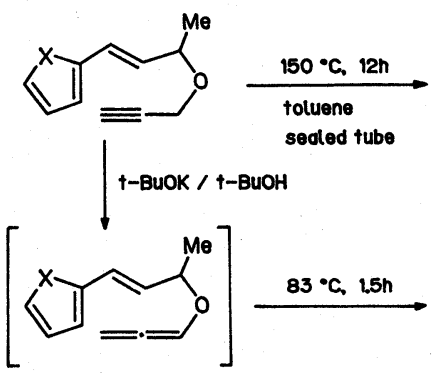

Fig. 11
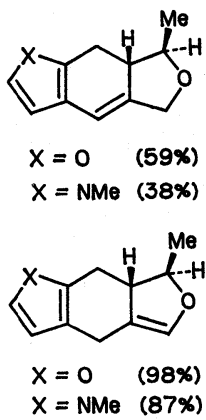

(CNDO/2)によるとプロパルギルエーテルとアレニルエ ーテル(それぞれメチルエーテルとして計算) は LUMO エネルギーレベル $(5.87 \mathrm{eV}$ と $5.15 \mathrm{eV})$ にそれ程大きな 差はなく，この顕著な反応性の違いを電子的効果によっ て説明することは困難である。従って，アレニルエーテ ル類の極めて高い反応性は主にアレンの幾何学的特性に 基づくものであろう。即ち，オレフィンやアセチレンを 親ジエン部分に用いた場合には遷移状態において矢印で 示すような非結合性 1,3-相互作用が存在し, 反応を立 体的に不利にするのに対し，アレンを分子内親ジエン部 分に用いると, その直交構造のためにジエンと親ジエン 部分が大した立体障害もなく容易に重なり合うことがで きる (図 12)。よって本反応の高い反応性はアレンの特

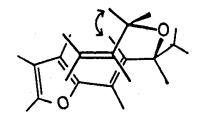

allyl ether

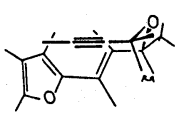

propargyl ether

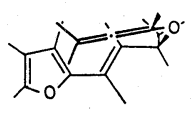

allenyl ether
Fig. 12

異な立体構造に起因するものであり，オレフィンあるい はアセチレン系親ジエン剤の場合しばしば必要とされる 電子的活性基を必ずしも必要としないという大きなメリ ットを有することになる。そこで，この極めて注目すべ き反応性を有機合成に有効に活用することを考えた。

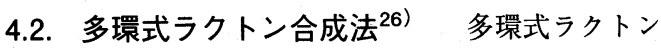
を部分構造に有する天然物にはナギラクトン類などの有 用な生理活性を示すものが少なくない。筆者らはアレニ
ルエーテル A の分子内 D.A.反応によりジヒドロフラン 誘導体 B が生成することに着目し，これに水和と酸化 を行い縮環式ラクトン Cへと変換することを考えた(式 2)。

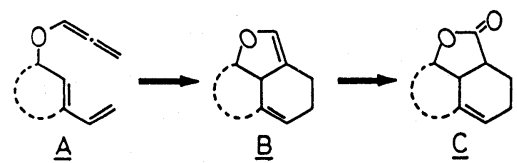

プロパルギルエーテル 39 を $t-\mathrm{BuOK}$ 存在下 $83^{\circ} \mathrm{C}$ に加 熱するとアレニルエーテル中間体 40 を経由して高収率 で D.A. 付加体 41 を与える。 41 は酸触媒存在下容易に 水和されてラクトール 42 を生成し, これを PCCで酸化 するとシス型に縮環したラクトン 43 が高収率で得られ た(図 13)。本法は一般性に富み, 表 3 に示す如く各種<smiles>C#CCOC1C=C(C=C)CC(C)(C)C1</smiles>

39

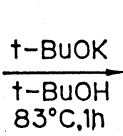
$83^{\circ} \mathrm{C} .1 \mathrm{~h}$<smiles></smiles>

40

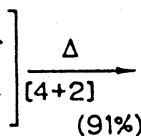

$(91 \%)$

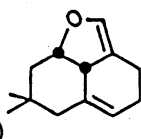

41

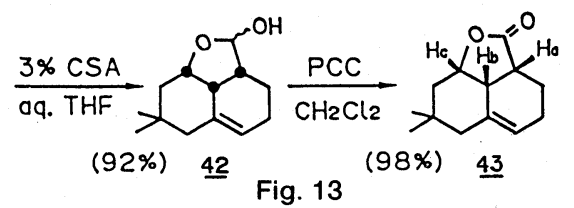

Table 3 Lactone syntheses via allene intramolecular cycloaddition and hydration-oxidation procedures.

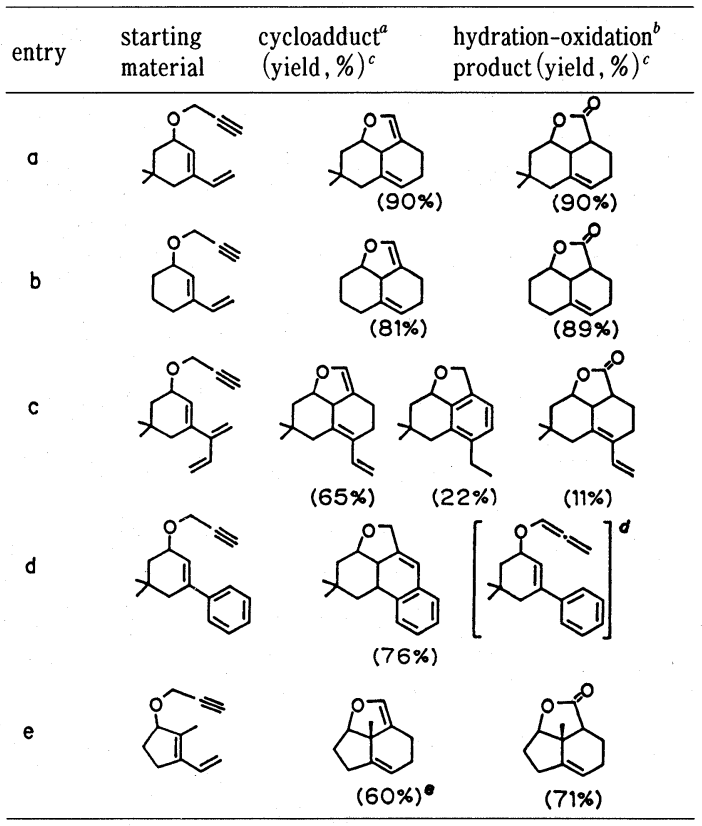

${ }^{a}$ Unless otherwise noted, all reactions were carried out in $t$ - $\mathrm{BuOH}$ at $83^{\circ} \mathrm{C}$ in the presence of 2 equiv, of $t$-BuOK. ${ }^{b}$ See the text. ${ }^{c}$ Isolated yields. ${ }^{d}$ Isolated in the reaction at $40^{\circ} \mathrm{C}$. ${ }^{e}$ An isomeric product was also obtained in $30 \%$ yield. 
多環式ラクトンを立体選択的に合成することができる。 本法の優れている点はアレンの極めて高い反応性をうま く活用したところにあり，D.A.反応に高温を要しない ため，重合や脱離等の副反応が殆んど見られない27,28)。

4.3. (土)-Platyphyllide の合成 ${ }^{26)}$ 上記のラク トン合成法を活用してノルセスキテルペン系天然物 Platyphyllide (50)の合成を行った (図 14)。アセトンと
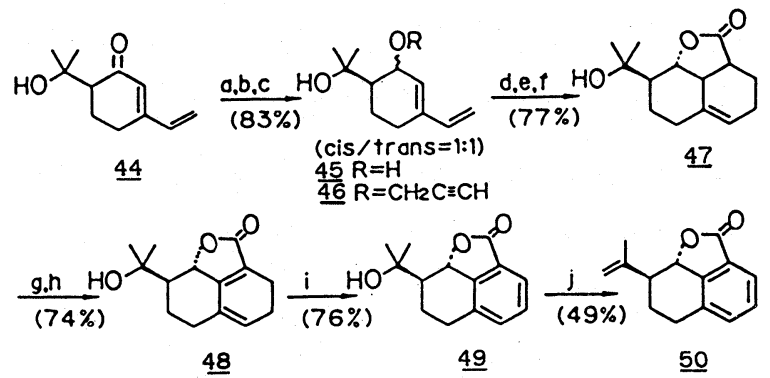

(o) LAH,E ${ }_{2} \mathrm{O}$. $-110^{\circ} \mathrm{C}$ : (b) n-BuLi,C6H6.OMSO, then $\mathrm{CH}_{2} \mathrm{CCH}_{2} \mathrm{Br}$ : (C) $\mathrm{SiO}_{2}-\mathrm{chr} .0-$

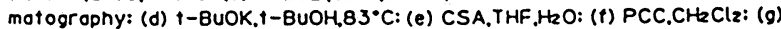
LDA.THF.then PhSeCl: (n) 30\% $\mathrm{HO}_{2} . \mathrm{CH}_{2} \mathrm{Cl}_{2}$ : (i) DOO.C6H6: (j) SOCl2.Py. $0^{\circ} \mathrm{C}$

Fig. 14

3-ビニルシクロヘキセンのアルドール反応によって容 易に得られる 44 を低温で $\mathrm{LiAlH}_{4}$-還元し，生じたアル コール 45 (cis/trans=1：1)を直接プロパルギル化した 後それぞれの立体異性体をカラムクロマトグラフにより 分離した。次に,より極性の高い trans-46を用いて今 回開発したラクトン合成反応を行うと, 極めて容易に且 つ立体選択的に反応が進行して三環式ラクトン 47 を $77 \%$ の収率で与えた。47は $\alpha$-セレノ化と酸化的脱離に より 48 とし, 更に DDQ で芳香族化して 49 へと変換し た後，側鎖の脱水を行うと $( \pm)$-Platyphyllide $(50)^{30 ） を ~}$ 結晶性化合物として得た。また，cis- 45 からも同様に して，50の epi-体である cis- 50 を効率よく合成するこ とができた。これらの結果は上記ラクトン合成法の有用 性を示すものである。

4.4. 連続的 $[2+2]+[3,3]$ 反応 ${ }^{31)}$ 分子内 D.A. 反応に及ぼす構造的要因について検討中, ジェン 部分 (2-位)に置換基を有するアレニルエーテル A は, 全く新しい転位反応 (連続的 $[2+2]+[3,3])$ を行い，一 挙に 3 環式エーテル B を生成することを見いだした(式 3)。

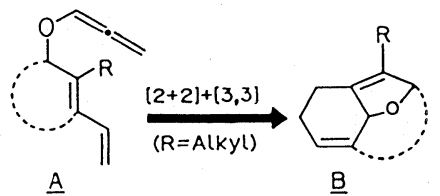

シクロペンテン誘導体 $51 \mathrm{a}$ (表 3; entry e) は $t-\mathrm{BuOH}$ 中 $t$ - $\mathrm{BuOK}$ 存在下加熱還流 $\left(83^{\circ} \mathrm{C}\right)$ すると速やかに反応 が進行して，通常の D.A.付加体 52a $(60 \%)$ と共に新規 エーテル化合物 53a(30\%) を生成した（図 15）。一方シ クロヘキセン誘導体 51b，54においては，同様な条件 下で後者のタイプの生成物 (53b，55)のみが高収率で生 成した (図 15)。これらの生成物の構造は接触水添やエ

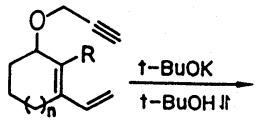

51 a. $R=M e, n=0$ b. $R=M e, n=1$

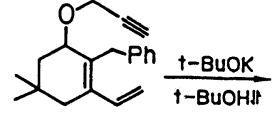

54

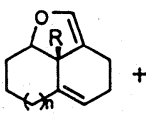

52 a. (60\%) b. (-)

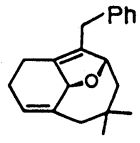

$\underline{55}$ (92\%)

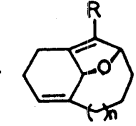

53 a. (30\%) b. $(88 \%)$
Fig. 15

ポキシド化などの化学変換によっても確認された。本反 応は図 16 に示す如く最初に生成したアレニルエーテル

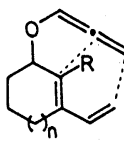

56 s-cis

$\sqrt{1}$

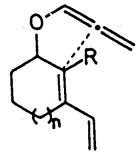

56 s-trons

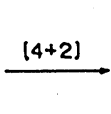

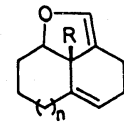

$\underline{52}$

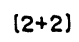

(3.3)

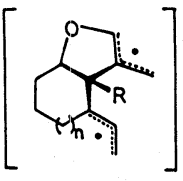

$\underline{58}$

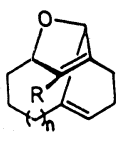

$(=\underline{53})$

Fig. 16

56 の分子内 $[2+2]$ 反応 (この場合おそらくジラジカル 中間体 58 を経由して進むものと思われる ${ }^{32-34)}$ と, これに続く 57 の最も歪みのかかった 2,3 -結合の開裂 を伴う $[3,3]$ 転位により合理的に説明をれる。この反応 が進行するには 2-位の置換基 $(\mathrm{R})$ の存在が必要不可欠で あり，これは R が 56 の $s$-cis 配座を立体的に不利にす ることにより，本来最も進行し易い分子内 D.A.反応を 阻害する働きをしているものと思われる。

本反応は操作が簡単なこと, 緩和な条件下でも高収率 で進行すること, 生成物の立体化学が予測できる等の特 長を備えている。そこで本反応をユニークな骨格と有用 な生理活性を有することで知られる夕キサンジテルペン 類 ${ }^{35 ）}$ の基本炭素骨格の合成に応用することを考え た ${ }^{31)}$ 。Wieland-Miesher ケトン $59 \mathrm{a}, \mathrm{b}$ を出発原料と して図 17 に示す方法で 2-位にアセタール置換基を有 

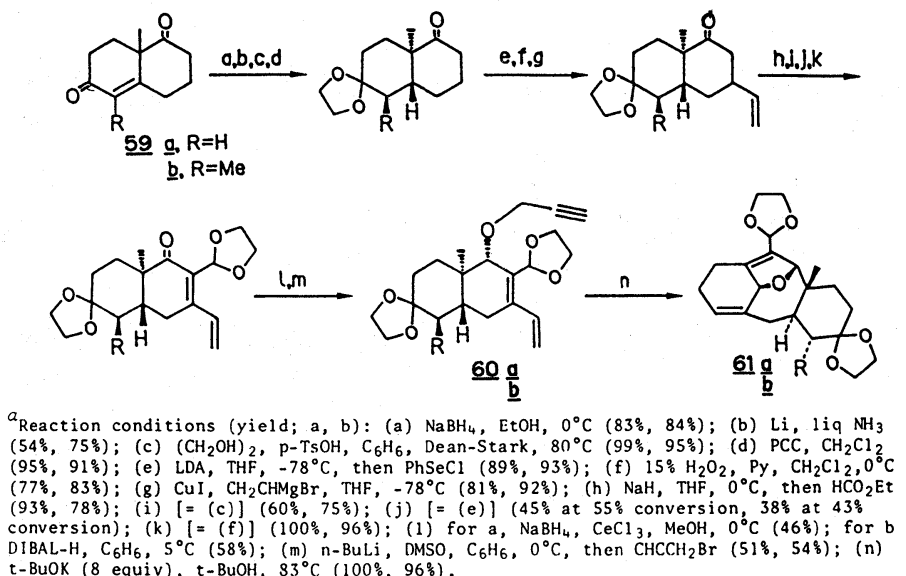

Fig. 17

するプロパルギルエーテル $60 \mathrm{a}, \mathrm{b}$ を合成し, $t-\mathrm{BuOH}$ 中 $t$ - $\mathrm{BuOK}$ と $83^{\circ} \mathrm{C}$ に加熱すると速やかに連続的 $[2+2]$ + [3,3]反応が起こり $61 \mathrm{a}, \mathrm{b}$ をほぼ定量的な収率で与 えた。本化合物は B,C 環が正しい立体で縮環したタキ サン基本骨格を有しており, 更に適切な位置に官能基が 存在するなど, タキサン類の有用合成中間体となり得る であろう31)。

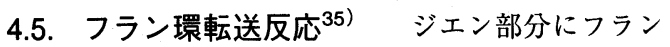
誘導体を用いたアレニルエーテルAの場合, 反応は D.A.付加に留まらず更に進行して縮環式フランBを高 収率で生成する(式 4)。プロパルギルエーテル 62 を $t$ -
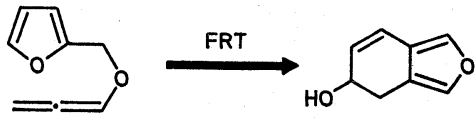

B

環式フランに変換する反応であり, 筆者らはこれをフラ ン環転送 (Furan Ring Transfer) 反応と名付けた。 生成物 65 は弱塩基性から中性にかけて安定に存在す るが，酸性にすると直ちに脱水して反応性中間体である イソベンゾフラン $66^{37)}$ を発生し, 各種ジエン化合物 と容易にD.A. 反応を行う (図 18)。即ち, 上記の FRT 反応はイソベンゾフラン類の新しい合成法としても有用 である。表 4 には各種置換体の FRT 反応とそれから発

Table 4 Furan ring transfer (FRT) reactions and the Diels-Alder reactions of isobenzofurans with DMAD. ${ }^{a}$

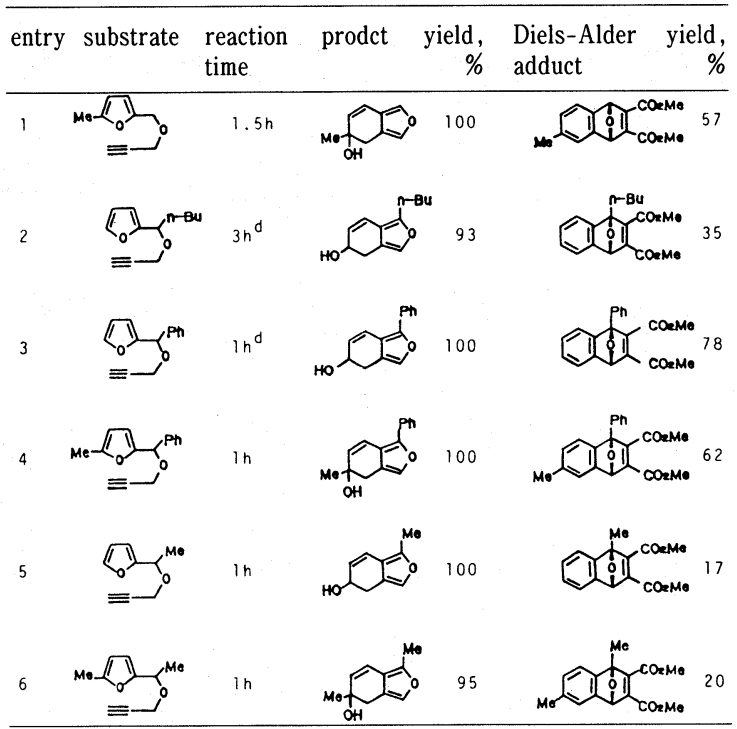

${ }^{a} \mathrm{The} \mathrm{FRT}$ reactions were carried out in $t-\mathrm{BuOH}$ at $83^{\circ} \mathrm{C}$ using 20 equiv. of $t$ - $\mathrm{BuOK}$, and the D. A. reactions were performed in THF at $25^{\circ} \mathrm{C}$ using 2 equiv. of DMAD and 1 equiv. of $p$-TsOH.

生するイソベンゾフラン誘導体とアセチレンジカルボン 65 $(98 \times)$

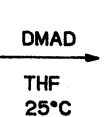

$(51 \%)$<smiles>FC1=C(F)[C@H]2O[C@H]1c1ccccc12</smiles>

$\mathrm{E}=\mathrm{CO}_{2} \mathrm{Me}$

Fig. 18

酸ジメチルエステル (DMAD) との D.A.反応についてま とめた。本反応は合成的にも有用であり，例之ば，プロ 
パルギルエーテル 67 はFRT 反応を二回連続して行い, 一挙に三環式フラン 68 を効率よく与える(図 19)。68
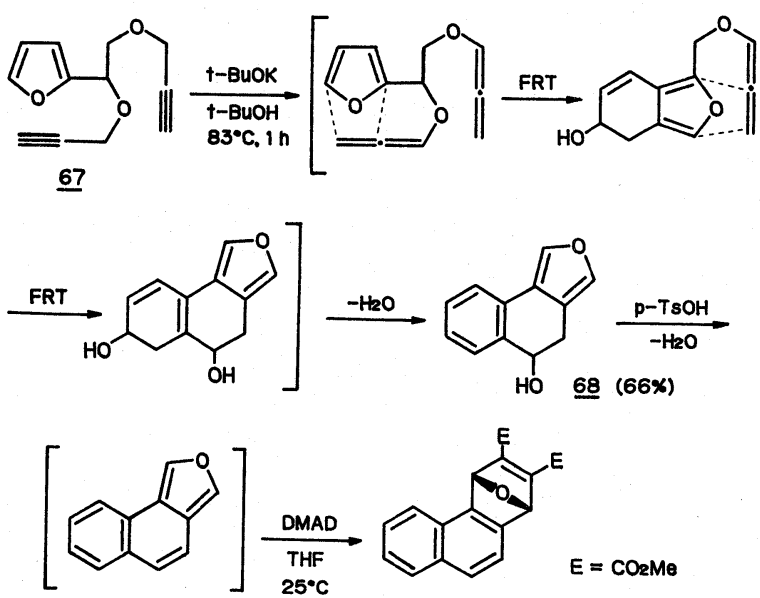

$\underline{69}$

Fig. 19

$70(65 x)$

は酸処理によりイソナフトフラン 69 を経由し, DMAD と D.A.付加体 70 を生成する。また，FRT とイソベン ゾフランの分子内 D.A. 反応を組み合わせることにより 多環式化合物に導くことが可能であるし $(71 \rightarrow 73$; 図 $20)^{36)}$, 二環式フラン 74 から出発してフラノセスキテ

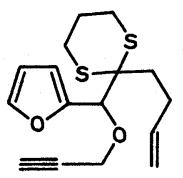

1ㅡ

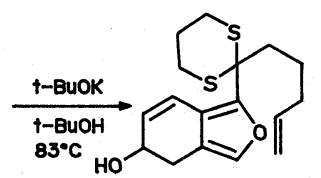

2ㅡ (80x)

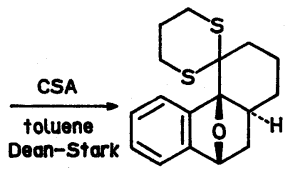

$\underline{73}(71 x)$

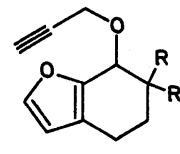

$\underline{74}$

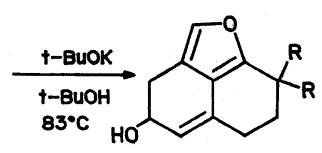

75 (>90x) a. $\mathrm{R}=\mathrm{H}$<smiles>[Pb]=C1SCCCS1</smiles>

Fig. 20

ルペン類の基本母格である三環式フラン 75 を一挙に構 築することもできる ${ }^{38)}$ (図 20)。

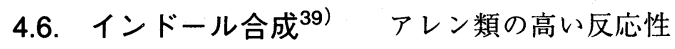
を窒素類縁体の分子内 D. A. 反応に応用し, インドール 骨格の新規合成を行った(図 21)。各種置換クロトンア ルデヒドとプロパルギルアミン誘導体からジエナミド

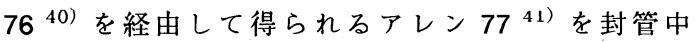
$160^{\circ} \mathrm{C}$ に加熱すると, 分子内 D. A. 反応が極めて容易に 進行し付加体 78 を高収率で与えた。2-および 7-位に 置換基がある場合, この分子内 D.A. 反応は更に容易に 起こる。次に，これを $\mathrm{DDQ}$ か或は $\mathrm{MnO}_{2}$ で酸化的に脱
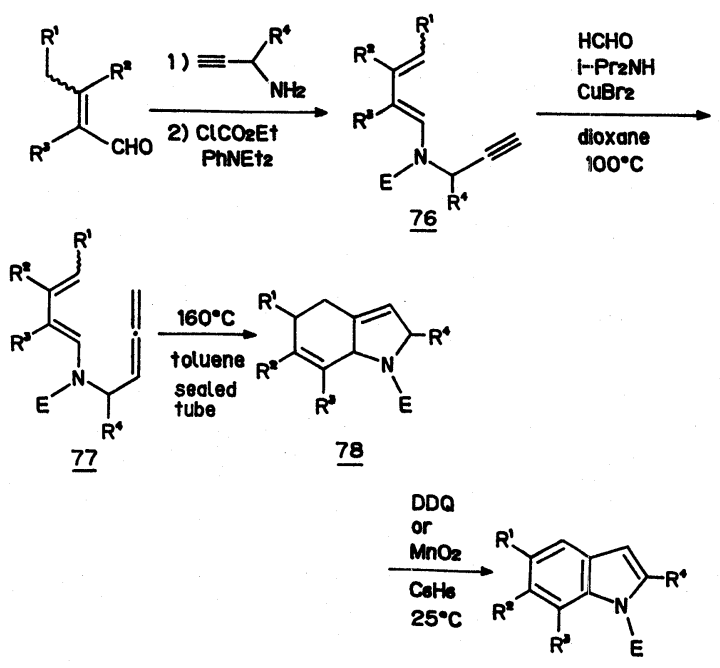

79

Fig. 21

( $E=\mathrm{CO}_{2} \mathrm{E} t$ )

Table 5 Indole syntheses via allene intramolecular cycloaddition and oxidation procedures.

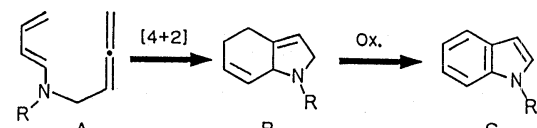

$\underline{c}$

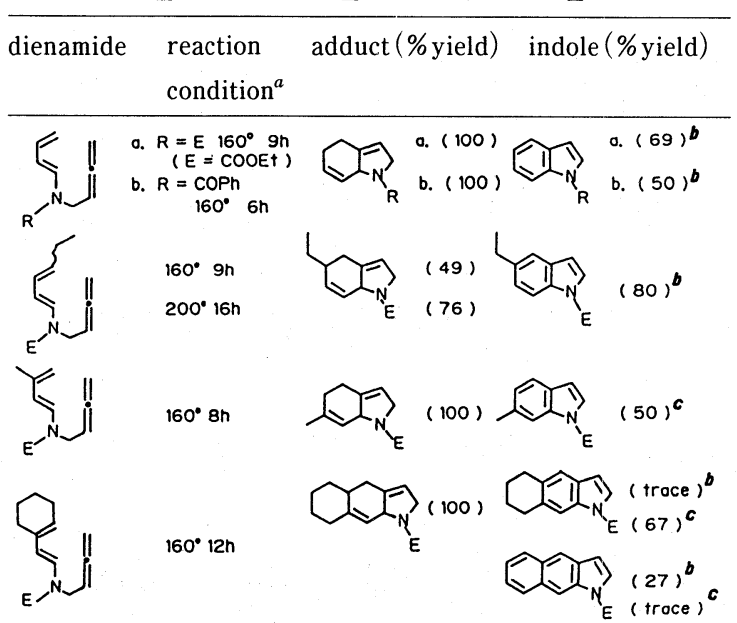

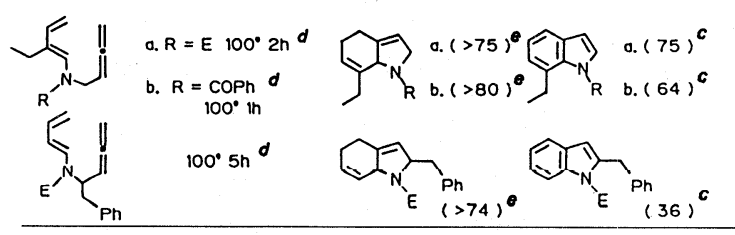

${ }^{a}$ All thermal reactions were carried out in a sealed tube (toluene). ${ }^{b}$ Oxidation method A: DDQ, $\mathrm{PhH}, 25^{\circ} \mathrm{C}$. ${ }^{\circ}$ Oxidation method B: activated $\mathrm{MnO}_{2}, \mathrm{PhH}, 25^{\circ} \mathrm{C}$. ${ }^{d}$ Cycloaddition occurred spontaneously under the conditions of allene synthesls. ${ }^{e}$ Over-all yields from the propargyl amides. 
水素芳香族化するとインドール誘導体 79 が効率よく得 られた(図 21)。この方法はアレンを親ジエン部分に用 いることにより分子内 D.A. 反応と共に脱水素芳香族化 をも容易にしている点が特徵である。本法による各種イ ンドール誘導体合成の結果を表 5 に示した。従来から インドールの合成は，殆んどがベンゼン誘導体を原料と するものに限られており，本法は非環式化合物から一段 階でインドール骨格を構築する点が極めて新規であり， 今後更に有効な有機合成への応用が期待される。

\section{5. おわりに}

ペリ環状反応を基本戦略に用いる新しい複素環合成に ついて，最近の著者らの研究を中心に分子間反応と分子 内反応に分けて紹介した。特に後者に扔いて，アレンの 幾何学的特性を十分に活用することにより，極めて高い 反応性を有する環状付加反応の開発に成功し，その有効 な活用例を示し得たことは注目に值する。これは，「環 状付加反応を容易に進行させるには電子的活性化が必要 不可欠である」という従来からの考え方を，ある意味で 打破するものであり，今後の有機合成を考える上で，一 つの指針を与えるものと思われる。

最後に本研究の推進にあたり終始ご指導賜った兼松顕 教授に心より感謝いたします。また本研究に協力された 当研究室の卒業生ならびに学生の諸氏(引用文献に記載) に感謝いたします。本研究の一部は文部省科学研究費 (昭 和 60 年一般研究C; 昭和 61 年試験研究) の助成を受け て行った。ここに記して謝意を表します。

(昭和 61 年 7 月 28 日受理)

\section{文献}

1）福井謙一, “化学反応と電子の軌道” 丸善 (1976)

2) R. B. Woodward, R. Hoffmann, "The Conservation of Orbital Symmetry"Verlag Chemie, Weinheim (1970); (訳書) 伊東, 遠藤訳 “軌道性対称性の 保存”広川書店 (1971)

3) I. Fleming, "Frontier Orbitals and Organic Chemical Reactions" Wiley, New York (1976); (訳 書) 竹内, 友田訳 “フロンティア軌道法入門” 講 談社 (1978)

4) G. Desimoni, G. Tacconi, A. Barco, G. P. Pollini, "Natural Products Synthesis Through Pericyclic Reactions" American Chemical Society (1983)

5) A. P. Marchand, R. E. Lehr (Editors), "Pericyclic Reactions" Vol I, II, Academic Press (1977)

6) T. Sasaki, K. Hayakawa, T. Manabe, S. Nishida, J.
Am. Chem. Soc., 103, 565 (1981)

7) K. Kanematsu, S. Morita, S. Fukushima, E. Osawa, ibid., 103, 5211 (1981)

8) S. Yoshino, K. Hayakawa, K. Kanematsu, J. Org. Chem., 46, 3841 (1981)

9) K. Hayakawa, M. Mibu, E. Osawa, K. Kanematsu, J. Am. Chem. Soc., 104, 7136 (1982)

10) K. Hayakawa, M. Aso, K. Kanematsu, J. Org. Chem., 50, 2036 (1985)

11) K. Hayakawa, H. Nishiyama, K. Kanematsu, ibid., 50, 512 (1985)

12) D. R. Taylor, Chem. Rev., 67, 317 (1967)

13) C. J. M. Stirling, J. Chem. Soc., 1964, 5856, 5863, 5875

14) I. Fujii, K. Ryu, K. Hayakawa, K. Kanematsu, J. Chem. Soc., Chem, Commun., 1984, 844

15) S. E. Denmark, M. A. Harmata, J. Org Chem., 48 , 3369 (1983)

16) K. Hayakawa, S. Motohiro, I. Fujii, K. Kanematsu, J. Am. Chem. Soc., 103, 4605 (1981)

17) K. Hayakawa, I. Fujii, K. Kanematsu, J. Org. Chem., 48, 166 (1983)

18) K. Hayakawa, Y. Kamikawaji, K. Kanematsu, Tetrahedron Lett., 23, 2172 (1982)

19) K. Hayakawa, Y. Kamikawaji, A. Wakita, K. Kanematsu, J. Org.Chem., 49, 1985 (1984)

20) K. Hayakawa, M. Takewaki, I. Fujimoto, K. Kanematsu, ibid., 印刷中

21) H. F. Schuster, G. M. Coppola, "Allenes in Organic Synthesis" Wiley, New York (1984)

22) K. Hayakawa, M. Yodo, S. Ohsuki, K. Kanematsu, J. Am. Chem. Soc., 106, 6735 (1984)

23) D. Kanne, K. Straub, J. E. Hearst, H. Rapoport, ibid., 104, 6754 (1982)

24) O. Dann, D. Volz, Arch.Pharm., 1975, 121

25) Y. Matsumura, J. Fujiwara, K. Maruoka, H. Yamamoto, J. Am Chem. Soc., 105, 6312 (1983)

26) K. Hayakawa, S. Ohsuki, K. Kanematsu, Tetrahedron Lett., 27, 947 (1986)

27) S. D. Burke, S. M. S. Strickland, T. H. Powner, J. Org. Chem., 48, 454 (1983)

28) S. J. Hecker, C. H. Heathcock, ibid., 50, 5159 (1985)

29) F. Bohlmann, K. H. Knoll, C. Zdero, P. K. Mahanta, M. Grenz, A. Suwita, D. Ehlers, N.Levan, W. R. Abraham, A. A. Natu, Phytochemistry, 16, 965 (1977)

30) F. Bohlmann, E. Eicheler, Chem. Ber., 112, 2811 (1979) 
31) K. Hayakawa, S. Ohsuki, K. Kanematsu, Tetrahedron Lett., 27, 4205 (1986)

32) M. Yoshida, M. Hiromatsu, K. Kanematsu, J. Chem. Soc., Chem. Commun., 1986, 1168

33) W. R. Dolbier, Jr., G. E. Wicks, J. Am. Chem. Soc., 107, 3626 (1985)

34) D. J. Pasto, Tetrahedron, 40, 2805 (1984)

35) R. W. Miller, J. Nat. Prod., 43, 425 (1980)

36) K. Hayakawa, Y. Yamaguchi, K. Kanematsu, Tetradron Lett., 26, 2689 (1985)
37) V. E. Wiersum, Aldrichimica Acta, 14, 53 (1981)

38）山口泰史, 早川謙二, 兼松 顕, 日本薬学会第 106 年会 講演要旨集 p. 403 (1986年4月 千 葉)

39) K. Hayakawa, T. Yasukouchi, K.Kanematsu, Tetrahedron Lett., 27, 1837 (1986)

40) W. Oppolzer, L. Bieber, E. Francotte, ibid., 1979, 981

41) P. Crabbe, H. Fillion, D. Andre, J. L. Luche, J. Chem. Soc., Chem. Commun., 1979, 859

○本会では会員のための欄が設けられておりますのでご利用下さい。!!

会員の声

\section{“こだま”欄について}

会員から開設の要望がありました会員の声欄を「こだ ま」という愛称名で第 34 巻から開設しています。

有機合成化学工業および技術に関連した興味ある話 題，有機合成に関した海外事情の紹介，本会に対する建 設的なご意見，ご提案等を歓迎します。

また会員相互の情報交換にもご利用下さい。

1. 原稿は 1 編 2 枚（本会規定の原稿用紙）以内を
原則とします。

2. 原稿には必らず氏名, 勤務先（または学校名）, 連絡先を明記して下さい。

(匿名希望の場合はその旨をお書き下さい。)

3. 原稿の採否決定は編集委員会にご一任願いま す。

4. 採用の原稿に対しては規定の原稿料をお支払い します。

5. 採否にかかわらず原稿は一切返却致しません。 会員諸氏は以上の要項に従って気軽にご利用下さい。 